\title{
EDITORIAL
}

\section{Bridging the Gap? The 1999 Annual Meeting of the American Society of International Law}

Keywords: American Society of International Law Annual Meeting; trends in international legal scholarship.

\begin{abstract}
The 1999 Annual Meeting of the ASIL exhibited a rare diversity of panels and speakers. The paradigm of an 'inclusive' professional community, shared by this Meeting, is well in line with a more general understanding of international law as an inclusive, unified discipline. This Editorial begins investigating this image of unity and its consequences for the ways 'difference' is encountered in professional debate.
\end{abstract}

This year's Annual Meeting of the American Society of International Law exhibited a rare diversity of themes and speakers. Panels on feminist approaches to international law, critical race theory, post-colonialism, followed others on the future of the Euro, the Pinochet case, and a simulation of the Kosovo crisis. The image of the international law academic as a cosmopolite, issues of sexuality in the liberalization of world markets, and the ethnology of international law, were to be found - alongside the WTO Shrimp/Turtle case and the role of international law in military decision making. Postgraduate students shared panels with military officers, activists, corporate lawyers, civil servants and professors. The meeting itself, which can be seen as part of a greater effort of the American Society of International Law to achieve a more diversified membership, was cochaired for the first time by two eminent scholars from the forefront of newstream writing, Professors David Kennedy and Berta Hernandez-Truyol. Old and new approaches, right and left, north and south, many were present at the Society last March. A hodgepodge collection, or the profession's components communicating with each other?

Most of us experienced the mixture as paradoxical from the beginning. The opening Grotius Lecture was an exchange between two of the profession's worthiest - yet most contrasting - scholars, Professor Nathaniel Berman and Judge Christopher Weeramantry. Characteristically, Berman simulated a dia-

1. Annual Meeting of the American Society of International Law, On Violence, Money, Power \&Culture: Reviewing the Internationalist Legacy, March 22-25 1999, Monarch Hotel, Washington, D.C. The Meeting has been recently reviewed also by J. Drolschammer, Jahrestagung der American Society of International Law (24-27 March 1999), 8 Actuelle Juristische Praxis 1030-1036 (1999).

12 Leiden Journal of International Law 505-509 (1999)

1999 Kluwer Law International 
logue between 'old' and 'new' approaches to international law in his speech. Through this imaginary dialogue, Berman spoke of the fundamental ambivalence at the root of international legal argument. He made the case for an exploration of this ambivalence through critical-genealogical scholarship. Judge Weeramantry acknowledged the significance of such newstream approaches for international law's ability to evolve, and emphasized the need for meaningful, engaged debate between 'old' and 'new' critiques. What a rare treat, I thought, thrilled by the exchange: the 'old' and the 'new' in international law finally addressing each other. Indeed some of the profession's most prominent figures from all corners of the discipline were present. For a younger jurist like myself, this seemed like tremendous news. Are we changing at last? This Meeting definitely felt like the closest one could get to a polyphonic, inclusive international law.

It comes to mind, however, that although the paradigm of an inclusive professional community has been introduced only recently to major international law conferences, it is not alien to international law at large. International lawyers are accustomed to thinking of international law as a unified, all-encompassing discipline. We traditionally use the term international law as something more than a catch-phrase for a bundle of unrelated norms, facts, opinions, and writing. Most of us understand the infinite variety of existing institutions, rules and procedures as adding up to a 'legal system', a 'regime', and so forth. We imagine that the various participants in transnational legal activity do comprise an 'international community', a 'society', or a 'global market', with a certain degree of coherence. We see international law scholarship as something more than a mass of dissociated individual research and writing projects: such works conjure up the corpus of the 'science of international law'. Similarly, we are accustomed to thinking of ourselves as parts of a relatively coherent universal professional community. Our individual projects, despite their diversity, do not fail to bind us together in the 'international legal profession'. Textbooks often picture international law this way. Introductory chapters initiate the reader to the 'general part' of international law, consisting of themes deemed common to all its fields. Doctrines such as the sources, legal personality, state responsibility and law of treaties are the most common examples here. Chapters on specific fields possessing a fair degree of autonomy follow: law of the sea; space law; diplomatic law; economic law; humanitarian law; human rights and so forth.

This representation carries substantial intuitive appeal. It portrays international law as an open-ended science, heedful of constructive criticism and attentive to change. It allows 'new' elements to formally enter professional discourse, but leaves the evaluation of their merit to the individual members of the professional community, and to the ability of the 'new' to convince and to prove itself. Indeed, the image of unity enables us to speak of a profession, of a community, of a science. It enables us to distinguish between ourselves and neighbouring sciences (private international law, domestic law, international relations, inter- 
national politics, philosophy); to place limits on the domain of international law, and thus defer topics and responsibility to others (question $\mathrm{x}$ belongs to the domain of politics or philosophy and not of law); to believe, when we gather in a conference room or publish a law review article, that there are a number of colleagues around the world ('the profession'), interested in what we have to say and sharing our language and anxieties about the 'international', even if they disagree with the substance of some of our claims. It also enables us to create international law's historicity, to see it as an entity with a past, present, and future, and to locate ourselves at the latest moment in the continuum.

Most importantly, however, the image of unity is useful in explaining change in international law. It provides the stock of weights and measures against which the 'new' is evaluated. It is generally admitted, for example, that there are peculiarities in the practice of some new fields of international law: the use of softlaw instruments; the tendency to blur distinctions between the public and the private, or between the national and the international; the relative lack of dispute settlement mechanisms and accountability; and so forth. These differences transcend classical disciplinary conventions. They are attributed, however, to the particular nature of the regulated subject-matter (the sensitive political nature of economic, environmental, and other issues involved; the right of certain groups of countries possessing the majority in some international institutions to utilize their power to create instruments; and so forth). ${ }^{2}$ Alternatively, they are regarded as 'technical' imperfections which will be remedied with the passage of time. Relative normativity, for example, is often seen as a 'remediable' part of the pathology of international law, attributed to its underdeveloped nature. ${ }^{3}$ On a different note, we agree that a feminist international lawyer and an intellectual property lawyer might have different professional projects in mind when they speak of reforming the international system. As long as their argument is 'scientific' and shares some of the generally accepted language and structures in the articulation of its claims, they are both located by colleagues in the joint professional community of international jurists. Few people would have difficulty in placing both the United Nations and the World Trade Organization in the same system of 'international law', although jurists involved in each one of these institutions would hasten to point out fundamental differences in their practices, assumptions, or visions of world organization. Although writers in international economic law claim that the field possesses characteristics so novel that they

2. See, e.g., R.R. Baxter, International Law in "Her Infinite Variety", 29 International and Comparative Law Quarterly 549-566, at 551 (1980); C. Chinkin, The Challenge of Soft-Law: Development and Change in International Law, 38 International and Comparative Law Quarterly 850-866, at 853 (1989); P.M. Dupuy, Soft-Law and the International Law of the Environment, 12 Michigan Journal of International Law 420-435, at 421 (1991).

3. The argument for soft-law as a manifestation of an imperfect legal order is advanced by, e.g., P. Weil, Towards Relative Normativity in International Law, 77 American Journal of International Law 413-442 (1983). 
constitute a 'revolution' in legal science, ${ }^{4}$ public international lawyers habitually explain international economic law as a newly emerged field of public international law. ${ }^{5}$

As long as rules, institutions or projects can be placed by the mainstream within the 'four corners' of the science (the generally accepted language, metaphors, style, structure of argument of the time), they are tolerated for their constructivism. Thus soft-law is tolerated if it can be explained through the lawcreating mechanisms stipulated in the classical doctrine of sources of Article 38 of the Statute of the International Court of Justice. The feminist critique can be admitted as permissible when it strips itself from its 'ideological' taint (the 'feminist' part) and criticizes law from a technical-scientific point of view. ${ }^{6}$ And international economic law can be explained as part of public international law through a limited set of shared doctrines and assumptions. ${ }^{7}$ In this sense, international law is an entity which exists beyond its branches, beyond the separate projects, beyond the individuals. It lives in the common themes and in their underlying assumptions, cutting through all its segments. 'International law', we utter, and the idea is that we all know what we mean.

What is troubling here is that the evaluation of the 'new' through the yardsticks of the 'old' may disempower its potential. The 'purification' of soft-law from those elements which transcend Article 38, of the feminist critique from its political/feminist twist, of economic law from its claims to interdisciplinarity, adds to a denial of the arguments themselves. In this process of evaluation and subsumption under existing discursive formations, the 'new' is represented: it becomes in a sense a form of art, over which the mainstream has the prerogatives of a critic. She may reject or endorse, like or dislike, but has no obligation to provide an engaged response.

Notions such as unity, the open-ended professional community, constructivism, are notions embedded in international law's understanding of progress. I have tried to briefly demonstrate how such notions may, on the contrary, conceal bias and exclusion. A lot of critical work engaged in a genealogy of international

4. See, e.g., J. Trachtman, The International Economic Law Revolution, 17 University of Pennsylvania Journal of International Economic Law 33-62 (1996).

5. For some classical arguments of this sort see G. Schwarzenberger, The Principles and Standards of International Economic Law, 117 RCADI 1-99 (1966-I); P. Weil, Le Droit International Économique: Mythe ou Réalité?, in Colloque D'Orléans, Aspects du Droit International Économique: Élaboration, Contrôle, Sanction 1-34 (1972).

6. See, e.g., the response to ferminist scholarship by Fernando Tesón: F. Tesón, Feminism and International Law: A Reply, 33 Virginia Journal of International Law 647 (1994). Tesón requests feminist scholars to demonstrate an intellectual 'purity' of position, free from those social and political factors which interfere with the goals of scholarly research. For a response to Tesón's critique, see Charlesworth [Cries and Whispers], at $558 \mathrm{et}$ seq.

7. See, e.g., the arguments in P.J. Kuyper, The Law of GATT as a Special Field of International Law: Ignorance, Further Refinement, or Self-Contained Regime of International Law?, 25 Netherlands Yearbook of International Law 227-257, at 228 (1994); W. Benedek, Die Rechtsordnung des GATT aus völkerrechtlicher Sicht (1990). 
law has put up a significant challenge on this front during recent years. ${ }^{8}$ On the closing day of the American Society Meeting, everyone agreed that it was a remarkable event, primarily on account of its polyphony. The doubt remained, however, as to whether in the polyphony of our professional socializing there was still room for meaningful communication. Artifacts of the 'old' can also serve as bases for a new literature, a new politics, even a new international law, as Nathaniel Berman suggested at the end of the Grotius Lecture. But can international law accept the challenge?

Thomas Skouteris

8. In a previous Editorial a Selective Bibliography of such work has been presented. See T. Skouteris \& O. Korhonen, Under Rhodes' Eyes: The 'Old' and the 'New' International Law at Looking Distance, 11 Leiden Joumal of International Law 429-440 (1998). 